\title{
The Particular Logic of Modernity
}

(c) David Kolb, 2000

A friend once said to me that he would be glad to discuss postmodernity if only he knew what modernity meant. There are so many descriptions. We're all modern: Modern society, modern art, modern philosophy, modern science, modern technologies. The reformation, the wars of religion, the American revolution, the French revolution, the Paris Commune, the world wars. Civil society, capitalism, the liberal state, the procedural state. Luther, Galileo, Descartes, Locke, Kant, Manet, Cezanne, Rawls, Warhol. But also Novalis, Nietzsche, Heidegger and the German cultural conservatives. Derrida, Bataille, Levinas, Pynchon. And so forth.

Here is Robert Pippin's enumeration of what he sees as the common features of modern societies: The new conception of nature required by modern science; the post-Cartesian notion of mind as subjective consciousness; a political world of passion-driven but rationally calculating individuals, or a 'post-Protestant' world of individually self-reliant, responsible agents; a new political language of rights and equality; and, most of all, a common hope: that a secular, rational basis for moral and political order could be found and safely relied on, could inspire the allegiance and commitment necessary for the vitality and reproduction of a society." (I 2) ${ }^{1}$

Hegel had his own theory of modern life and thought, centering around the culmination of spirit's teleology in objective and absolute spirit, based on the logical patterns of the movement of spirit's development. Modern times brought decisive liberations and completions, but also permanent tensions, and a loss of immediate rootedness in a natural or social home. Modern selves are strong enough to be bei sich in the midst of modern tensions and negativities, but it takes work and maturity to deal with the inner complexities of modern thought and the built-in tensions of modern institutions.

However, despite all the inner tensions he described, Hegel disagreed with theorists who saw modernity as the achievement of a divided reflective self. He wanted to move beyond ironic awareness, utilitarian calculations, and the romantic and reflective divisions characterized by the categories of essence. Irony and reflection were to find their place within a new immediacy of modern structures and institutions. The term "immediacy" is too strong for what Hegel is proposing, but I use it to stress how for him permanent tensions and dialectical dualities and the work of the negative do lead to relatively stable modern structures of self and society. Even though they contain much inner tension, they do not imply permanent revolution.

But permanent revolution is just what many would argue should be distinctive of modernity. If Hegel 
should be thought as somewhat non-modern, this would be in his belief that there are structures of movement and institutional frameworks that are not themselves open to revision. There are the categories of the logic, there is the final religion, there is the state with its institutions, its puzzling agricultural class, and its national spirits. This offends those devoted to eternal reflection and ongoing contestation. They dismiss Hegel, or, if they are sensibly Hegelian, they make his recommendations more general, remove these details, and revise him into a proponent of endless progress.

Yet Hegel reasserts the state above the dynamism and freedom of civil society. In Hegel's description of civil society the parameters that open the space of social possibilities are set by arbitrary will (contract), brute nature (physical needs), and social contingency (the indefinite multiplication of needs in the market). The space of possibilities so constituted has little internal shape and allows almost unlimited circulation and substitution. For Hegel the space of social possibilities must allow individuals and groups to achieve a social identity that is integrated into a structured whole of social possibility, rather than sliding around in the shifting circulation of civil society. The unity of the state must be expressed in institutions and functional divisions that connect with the concrete rationality of intersubjective community rather than with the formal rationality of the market. The moments of universality, particularity, and individuality must be mediated through structures that open the distances and articulations that make social life possible.

These days Rawls and many others argue that a decisive modern invention is the liberal procedural state that allows its citizens their own autonomy and their own multiple conceptions of the good. Local institutions should be set up as if chosen by autonomous modern citizens in accord with procedural meta-institutions. But for Hegel, to claim that modernity gives us meta-institutions for generating detailed local institutions would be to claim that a species of formal universality was enough. We know that Hegel's state does more than supervise procedures. His views on the role of public opinion differ from standard liberalism, his Estates are not a normal liberal legislature, his agricultural class is to live in immediate unity with the values of the national spirit. Today's religious and nationalist fundamentalisms may react against modernity, but might Hegel might agree with them that there is a problem with modern formal identity.

All readings of Hegel agree that our awareness of the workings of the modern world is part of that working. But not all readings would agree about the place of particularity in that work.

From his early writings on Hegel worries about modern dichotomies. He encompasses modern splits within a movement that enfolds within itself any attempt to establish a position beyond or outside itself. He is not unique in this strategy; besides Hegelians, we find related moves in Nietzsche, in Heidegger's step back and its hermeneutic successors, in deconstruction, in Habermas' dialogic rationality, and in pragmatists such as Rorty. Among that group, Hegel demands the most, since he wants that enfolding overarching movement to imply more definite particularity. 
The abstract issues here concern the status of formality (formal syllogisms, formal judgments, formal analyses, formal processes). Are there further conditions of possibility for form/ content distinctions? Or is some kind of form/content distinction the ultimate intellectual gesture? Is some set of procedural moves, accompanied by contingent content, the ultimate political move? Is a formal self-consciousness of ourselves as criticizers and innovators of structures our ultimate modern home? Or are all of these located within a movement that cannot be described in terms of form and content?

Many readers of Hegel today, and many other theorists of modernity, would argue that formality has the first and last modern word. ${ }^{2}$ In Max Weber's terms, to be modern is to have made the move away from substantive rationality and ways of life that depend on comprehensive cosmic doctrines. Whether you then agree with Weber that modern formal rationality is instrumental rationality writ large, or with Habermas that modern rationality has other richer dimensions, you are still accepting that to be modern is to move to a formally defined identity. Of course there must be contingent content, but what makes your identity modern is your awareness of the difference between form and content, and your manipulation of the content within the formal features of subjectivity and community.

Hegel stands with Heidegger and deconstruction in denying the ultimacy of the form/ content division. I take Hegel as asserting that formal processes or distinctions are only possible within some fuller motion that cannot be described in those (Verstand) dualities, and that our full modern identity involves a selfawareness of being in that motion that is more than distinguishing a form from content.

Consider interpretations of Hegel as a partisan of unending open contestation. Robert Pippin's interpretation of Hegel and modernity is more complex and nuanced than the formal openness I will be considering, but his statements can be used to evoke a class of readings of Hegel. Pippin rejects the details of Hegel's grand narratives:

It is unlikely that so much, from the exhaustion of Greek tragedy, to the paradoxes of Roman law on property, to Leibniz's failed monadology, can be linked to a developing self-consciousness about the very possibility of "positions" or "theories" or philosophy ....

Instead, Pippin sees Hegel as promising a kind of unending contestation about any fixed points or settled results, a modernity necessarily unending and unsettled. (I 414)

Using the language of the logic of essence, Pippin says that

Truly determinate reflection is not a resolution of the opposition between positing and external reflection, but a continuation of such a constantly unstable reflective enterprise in a suitably self-conscious (and so, in a speculative sense, satisfied) way." (H 257) [The logic provides] an absolute comprehension of the nature of the incompleteness of thought's determination of itself, of the necessity for reflectively determined Notions, and 
yet the instability and ultimate inadequacy of those Notions. (H 257)

These statement are emblematic of readings of Hegel that interpret the dialectical process as ongoing selfcriticism and self-creation. ${ }^{3}$

I would like to argue that such readings over-emphasize the logic of essence, and that they reduce modernity to a matter of formal universality, and keep Hegel too much on a meta-level. That is what I would like to argue, but the case is not so clear. Such readings of Hegel are not just Heideggerian or postmodern celebrations of the lack of mediating structure in modern society. These readings of Hegel insist that spirit must find itself in some objective structures and patterns of mutual recognition, and that typically modern institutions are needed for full self-consciousness. They affirm that the creation of new mediating structures happens through something like a dialectical process. Pippin rejects the notion of determinate negation, but he insists that structures are constantly compared with an ideal of full selfconsciousness. This gives direction to the process, even if it does not provide necessity for any given transition.

Hegel argues that for modernity certain definite mediations and structures are necessary. He also insists that such structures be explicitly posited (in the logic, in social institutions, in art works) rather than merely acknowledged in a private reflective grasp. This second issue is the key to the first, as it is the requirement for explicit positing of spirit's moments that establishes the particularity of the structures.

The divine idea is just this: to disclose itself, to posit this other outside itself and to take it back again into itself, in order to be subjectivity and spirit. (E §247z)

The Concept is the ground and source of all finite determinateness and manifoldness. (WL 12.22 / 2.227 / SL 589)

Spirit is not ... an essence that is already finished and complete before its manifestation ... but an essence which is truly actual only through the specific forms of its necessary self-manifestation. (E §78z)

Spirit comes to itself through the positing of particular structures.

Since it contains all determinateness within it, and its essential nature is to return to itself through its self-determination or particularization, it has various shapes, and the business of philosophy is to cognize it in these. (WL 12.236 / 2.484 / SL 825)

How far does that self-determination go? We are familiar with the embarrassments caused by Hegel's willingness to descend far into the realm of the particular. ${ }^{4}$ For instance, in discussing geological stratification and the arrangement of the continents, he claims that

The general law of this sequence of formations can be recognized without any reference to the historical aspect; that is the essential point--this is the rational element which alone has interest for the Notion: to recognize in this sequence the characteristics of the Notion.... [The arrangement of the continents] appears at first to be accidental; but the activity of the Notion is to grasp as necessarily determined what to sense-consciousness 
appears as contingent. Contingency certainly has its place too, but only in unessentials... The Old World exhibits the perfect diremption into three parts, one of which, Africa, the compact metal, the lunar principle, is rigid through heat, a land where man's inner life is dull and torpid--the inarticulate spirit which as not wakened into consciousness; the second part is Asia, characterized by Bacchanalian extravagance and cometary eccentricity, the centre of unrestrained spontaneous production, formlessly generative and unable to become master of its centre. But the third part, Europe, forms the consciousness, the rational part, of the earth, the balance of rivers and valleys and mountains--whose centre is Germany. The division of the world into continents is therefore not contingent, not a convenience; on the contrary, the differences are essential. (E §339z2)

Faced with such implausible claims about the details of nature, it is tempting to defend Hegel by retreating to a more general level. For instance, we might disdain his argument about the continents, but still admit that certain very large divisions of nature do need to be thought as conceptually necessary. Or we might say that we find the details of his proposed state legislature unconvincing and unnecessary, but that he has rightly shown the necessity for a mediation of the aspects of society that the legislature is supposed to unite, though various kinds of legislatures could accomplish that mediation.

Hegel is surely not deducing Krug's pen. But to see the issue as a dispute over the degree of generality or formality appropriate to Hegel's conclusions misses the main issue. That issue is not what level of formal self-definition modernity entails. The issue is formality itself. The dichotomy of form and content is the wrong way to talk about Hegel's encompassing motion of thought. That motion is self-conceived in the absolute idea, as it is spelled out in third part of the logic, where the idea's structure and movement appears in the mediations of judgment and syllogism, universal, particular, and individual.

Hegel would argue that the absolute idea conceives a space or space-ing or motion that cannot be described in terms of a form/ content distinction, and within which that distinction arises. The question then becomes how determinate and how self-consciously particular must the moments of that motion be? For it might seem that the absolute idea itself could be just a higher level formal analysis.

Consider a parallel from Hegel's aesthetics. Hegel sees romantic art as going beyond the divisions of form and content, inner and outer, that were so harmoniously balanced in classical art. However, this is not because romantic art achieves a new higher level of form. Rather, the motion of romantic spirit can no longer be described in form/content terms. The romantic cathedral abandons the classical temple's clear form and offers instead a bewildering multiplicity of detail and decoration in a complex divided space within a solid shell that seems intent on both showing its weight and dematerializing itself. The experience of the cathedral puts us within a motion inward and upward that cannot be fully embodied in frozen matter because it is a motion away from the outerness of matter, a motion that cannot be described 
as a form/content distinction because it poses and moves over and through such distinctions. With the awareness of that motion the balanced dichotomies of classical art now appear as a lovely moment of stasis within a process that those dichotomies can neither describe nor explain.

But the resolved dualities of the classical were not the first form of art. The classical must be preceded by the imbalances of symbolic art. First there had to be posited abstract or isolated versions of those moments that will be united in classical art. So there were first the excesses of symbolic art, where form and content, inner and outer, failed to come together; symbolic art asserts the independence of each component, while classical art unites them by being their more concrete mediation. Then classical art's balances will themselves turn out to be abstract and isolated moments within the fuller motion of romantic art. These moments must first be posited in their separation and their abstractness so that they can be picked up into the motion of the spiritual totality.

[Classical art's] appropriate content is the spiritual individuality which, by being the content and form of what is absolutely true, can appear in consciousness only after complex mediations and transitions. The beginning is, as a beginning, always abstract and indeterminate. But spiritual individuality must be concrete in and for itself. It is the adequate actualization of the Concept that determines itself out of itself, which can be grasped only after it has sent ahead [presupposed,vorausgeschikt], into their one-sided development the abstract aspects whose mediation it is. Once this happens, the Concept makes an end of these abstractions together by its own appearance as a totality. ${ }^{5}$

Hegel says that in romantic art, God is not the perfect Greek statue in the central temple balancing infinite and finite. Rather, the romantic God is the very movement between the finite and the infinite (Gott als dieser Wechsel (A 13.119)). God is not form, nor content, God is their exchange and mediation. That is what modern self-consciousness should be. The process is self-present only by being the mediation of its own already posited incomplete and abstract moments.

The same principle applies in nature, in the historical stages of spirit's formation, and in contemporary politics where the concrete totality is achieved by mediating the posited abstract or isolated versions of the constitutive moments. These are not arbitrarily contingent content, nor Heideggerian facticity; they are the necessary moments deren Vermittlung is the concrete whole.

Hegel's Begriff is not a Spinozistic substance with infinite attributes. Its content is restricted, because its content is its own necessary mediations. Spirit comes to be through bringing together its own motions posited abstractly and incompletely. The positing of these particular moments, motions, and mediations is the birth -- and the holding open -- of the space of reasons and of mutual recognition, and through that movement that space comes already inherently structured.

Hegel is willing to use form/ content language to talk about the absolute idea, but he turns that language on itself when he insists that the content is the progression of the moments of the form. "The logical idea 
has itself as the infinite form for its content"6

The manifestation of itself to itself is therefore itself the content of spirit and not, as it were, only a form externally added to the content; consequently spirit, by its manifestation, does not manifest a content different from its form, but manifests its form which expresses the entire content of spirit, namely, its self-manifestation. (E §383z) ${ }^{7}$

The relation of the movement of spirit to its particular determinations is not that of external form to content, nor quite that of universal to particulars; it is the relation of the absolute idea to the earlier categories in the logic, and then the relation of the logic to the Realphilosophie. Philosophy does more than oppose necessary form to contingent content.

In contrast to the empirical sciences ... speculative thinking has to demonstrate each of its objects and the explication of them, in their absolute necessity. This is effected by deriving each particular concept from the self-originating and self-actualizing universal concept, or the logical idea. Philosophy must therefore comprehend spirit as a necessary development of the eternal idea and must let the science of spirit, as constituted by its particular parts, unfold itself entirely from its Concept. (E §379z)

Over and over Hegel makes the same point. The process is the revelation of itself, but not of itself as formless energy or formal meta-position. For example, when Hegel disparages the physics of his day he makes a criticism similar to his his argument for the state as a more concrete universal than civil society.

The inadequacy of the thought-determinations used in physics can be traced to two points which are closely bound up with each other. (a) The universal of physics is abstract or only formal; its determination is not immanent in it and it does not pass over into particularity. (b) The determinate content falls for that very reason outside the universal; and so is split into fragments, into parts which are isolated and detached from each other, devoid of any necessary connection, and it is just this which stamps it as only finite. (E §246z)

I have been arguing that for Hegel modern spirit posits and conclusively mediates determinate moments in its coming to itself. Its moments are the large defining movements of the system: in itself, for itself, in and for itself; being, essence, concept; universal, particular, and individual. These are elaborated in the doctrine of judgment and syllogism, and then self-reflected in the discussion of method in the absolute idea. They may seem quite general, but they are involuted into one another and repeated fractally on different scales to provide more determinate content that is the manifestation of spirit's form, which is its process of coming to itself, which is its self-manifestation. These moments must first be posited in their separated or abstract, form, and then mediated into a whole in which they find their proper place, so Hegel's modern spirit is not, as Pippin would have it, "a kind of unending contestation about any fixed points or settled results, a modernity necessarily unending and unsettled." (I 414) ${ }^{8}$

Hegel does, then, challenge some current ideas about modernity. For him, self-creation and self-assertion, and spontaneity and autonomy, all involve the explicit positing and mediation of determinate moments, 
not a formless creativity facing brute fact. That process needs procedural institutions, but it also needs immediate values that involve the explicit expressions of the process's built-in moments, divisions, and tensions. Those immediate values and partial identities are embodied in contingent ways, but it is not contingent what moments they are. This argues against the reduction of everything to reflection, and against both a conservative flight to fixed natural values and an easy postmodern irony.

If we were to accept this teaching, it would have implications about the relation of modern institutions to groups and institutions that do not accept liberal values. Hegel defines a modern "we" that transcends particularistic identities without being just formally universal. He would see current religious or ethnic particularist identities not as external elements or anti-modern reactions, but as isolated moments of the modern process of self-affirmation. His awkward descriptions of the national spirits of various European peoples show his concern that these identities embody defined aspects of spirit's process. He would urge that today's groups be mediated out of their isolated absoluteness, but not melted down to some least common identity. ${ }^{9}$ If Rawls's criteria for political liberalism were used to question his neutrality, Hegel would argue that his reasons lie not in some particular cosmological view but in the conditions that make possible any view at all.

There is much that we could gain from considering Hegel's views on these matters. But there would be a price to pay. Can we accept that the particular determinations of social groupings and functions are so necessarily determined ${ }^{10}$ Hegel's descriptions of the to-be-mediated others imperialistically assign to them what their self-understanding must already be.

I have been arguing that for Hegel the particularity within modernity comes from the determinacy of the logical movements of the system as they involute upon one another. But we may not be quite so sure about the severe necessity of the logical progression. ${ }^{11}$ Does what Hegel says about mediating structures depend on an untenably strict view of the necessity of determinate negation? Without strong determinate negation generating a firm list of moments to be posited, would modernity be reduced to a formal process facing brute givens?

I do not think that is quite where we would end up, for we could still hold to Hegel's insight that there is no formally defined activity that can be posited a such. The underlying issue concerns the conditions of the possibility of formalism. My own preference would be to agree with Hegel that form/ content distinctions happen within an overarching motion that allows no distinctions except within itself, and that cannot itself be analyzed using form/ content distinctions. But, disagreeing with Hegel, such a motion can be self-referential without closure or self-transparency.

Can we find ourselves within a motion that enfolds and originates dichotomies, especially the form/ content dichotomy, yet without being able to provide a definitive logical analysis of that motion? The motion would be indirectly known and invoked, but not presented. Modern formal analyses and formal 
institutions would be within a movement that posits them as not the whole story, finds itself in exceeding them, in exposing them, but does this in a way that reveals as well its own impurities.

This line of thought argues with Hegel about transparent self-return. We could modify Hegel's insight that the form of the motion becomes its own content, because the overarching process does not have a proper form. This claim shares argumentative terrain with Pippin and others but lacks the self-sure formality of their interpretations. Instead it moves closer to deconstruction and hermeneutics, and so into debates with Heidegger, with Derrida, and with Ricoeur.

Hegelian echoes are cheerfully invoked in hermeneutics and grudgingly admitted in poststructuralism. Like Hegel, the poststructuralist invokes an overarching motion that is not analyzable in form/content terms. Hegel's positing and then mediating of abstract partial identities turns into the necessary projection of excessive unity -- necessary after the manner of Kant's necessary illusions of reason -followed by a deconstruction of those unities. Some poststructuralists eager for social analysis then rush to identify these moments with particular social groups, hierarchies, or avant gardes. The impatient poststructuralist should conclude, however, that the overarching process that is the condition of visibility cannot itself be made visible or invoked as a political player, though it can be indicated by a gesture not unlike Hegel's refusal to see partial moments as final wholes.

Lacking Hegel's definitive list of necessary moments, we would still find our own factical mediations through a hermeneutics, suspicious or not, of current institutions. This would, I think, lead to a version of Hegel's discussion of the relations of civil society and state. Knowing how to be modern would be knowing how to live with and in these structures and processes while not identifying with any one of them, even those more formal and free. This is close to Hegel's positing them as moments, except without a self-transparent rational totality. ${ }^{12}$

Would this imply a challenge to the claim that modernity is unsurpassable? If the argument that modernity is the final shape of spirit depended on the purity of the self-return involved, and if that purity were questioned, then modernity would be reduced to one among many possible stories and historical forms. But I would argue that the purity and formalism of modern self-consciousness are not the essential marks of modernity. The defining modern stance is a self-awareness of the overarching process within which stories and historical forms appear. Purity and formalism are one mode of that self-awareness, though, oddly enough, a mode that is not yet sufficiently purified of certain traditional dichotomies. Still, there is a distinctive modern stance from which any reimposition of fixed ultimate dichotomies would be a regression and not just a change ${ }^{13}$. 
Press, 1997), hereafter referred to as "I". Abbreviated references will also be made to Pippin's Hegel's Idealism: The Satisfactions of Self-Consciousness (Cambridge: Cambridge University Press, 1989), referred to as "H", and to Hegel's Encyclopedia ("E" followed by section number) and his larger Logic ("WL" followed by page references to the Gesammelte Werke, vol. 12 (Hamburg: Meiner, 1981), to the Philosophische Bibliotek edition of the second volume of the Wissenschaft der Logik, vol 2 (Hamburg: Meiner, 1963), and to the Miller translation (Hegel's Science of Logic (London: Allen and Unwin, 1969), indicated by "SL".

2 In this essay I emphasize theories of modernity that stress its formal processes and institutions. There is a related approach that is often found in the same thinkers, stressing the differentiation and independence of spheres of thought and value. Hegel also relates ambivalently to those theories. He would agree that modern art and politics have won their freedom from comprehensive cosmological doctrines, and that modern thought cannot be drawn from a substantive doctrine of nature. The normative must be separated from the natural, as pure thought must be separated from images. However because of the self-generation of pure thought, the various spheres do not go their own way. Or, rather, their differing ways are all opened by the same logical progression, embodied and further determined differently.

3 Pippin insists that as an outcome of our history there must be a self-reflectively legitimated rational process of self-orienting. This is more than formal self-consciousness facing factical givens. That is how the process of development starts, but as it goes along current practices are found insufficient by their own implied criteria. Differing from Hegel, Pippin argues that these failures motivate but do not define replacement practices. The new is justified because retrospectively it redoes the old better, but what it redoes becomes defined more and more in terms of autonomy. The failures of practices and social arrangements to meet their own goals are all due to built-in frustrations of or lack of acknowledgment of the autonomy of conceptual construction. Through the failures of local projects, it gradually becomes clear that there is really only one fundamental project, autonomy. Then that purer project can be taken up self-consciously as our goal, which happens in modern institutions and self-consciousness. In explicating this, Pippin combines Nietzschean and Kantian themes: "The ultimate Hegelian claim is that the problem of self-definition or identity is a problem of social power, not metaphysical truth, and that this process has a certain "logic" to it. (I 424) "There is no ... external point of view, and so 'we,' ourselves inheritors and products of such selftransformations, must understand how such institutions and practices have come to assess themselves, what sort of reassurance they have achieved, how satisfying they have turned out to be, 
how they have led to 'us."' (I 336) We justify our practice by a historical account combined with the demonstration that the changes occurring in that history were rationally acceptable replacements for what was wrong with prior formations. The story of that process will reveal that the "basic failures are always due to the denial of ... conceptual autonomy." (I 172)

4 Hegel makes similar claims about the logical basis of developments in the histories of religion and philosophy: "The Bible is for Christians the basis ... which strikes a chord within them, and gives firmness to their convictions..... But just as soon as religion is no longer simply the reading and repetition of passages, as soon as what is called ... interpretation begins . . . certain presuppositions are made with regard to this content, and ... everything depends on whether this content is true.... [The content] can only be forms that are genuine and logically developed in terms of necessity. But the investigation of these forms of thought falls to philosophy alone." (Lectures on the Philosophy of Religion, ed. by Peter Hodgson (Berkeley: University of California Press, 1988), 399-402). "Nach dieser Idee behaupte ich nun, dass die Aufeinanderfolge der Systeme der Philosophie in der Geschichte dieselbe ist, als die Aufeinanderfolge in der logische Ableitung der Begriffsbestimmungen der Idee." (Berliner Niederschrift 1820, in Einleitung in der Geschichte der Philosophie; (Hamburg: Meiner, 1940), 34).

5 This passage is from Hegel's Vorlesungen über die Ästhetik (Frankfurt: Suhrkamp, 1986), vol. 13, 411. The translation is modified from T. M. Knox's Hegel's Aesthetics (Oxford: Clarendon, 1998), vol. 1, 317).

6 "The logical idea has itself as the infinite form for its content -- the form which constitutes the opposite to content to the extent that the content is the form-determination withdrawn into itself and sublated into identity in such a manner that this concrete identity stands opposed to the identity developed as form. The content has the shape of an other and a given as against the form which as such stands simply in relation, and whose determinateness is at the same time posited as appearance. More exactly, the absolute idea itself has for its content merely this, that the form determination is its own fulfilled totality, the pure concept. The determinateness of the Idea and the entire course followed by this determinateness is the object of the science of logic, from which course the absolute idea itself has emerged for itself. It has shown itself for itself that determinateness does not have the shape of a content, but exists wholly as form, and that accordingly the Idea is the absolutely universal idea." (WL 12.236 / 2.485 / SL 825)

$7 \quad$ The entire passage reads: "The manifestation of itself to itself is therefore itself the content of spirit and not, as it were, only a form externally added to the content; consequently spirit, by its 
manifestation, does not manifest a content different from its form, but manifests its form which expresses the entire content of spirit, namely, its self-manifestation. In spirit, therefore, form and content are identical with each other. Admittedly, manifestation is usually thought of as an empty form to which must still be added a content from elsewhere; and by content is understood a beingwithin-self which remains within itself, and by form, on the other hand, the external mode of the relation of the content to something else. But in speculative logic it is demonstrated that, in truth, the content is not merely something which is and remains within itself, but something which spontaneously enters into relation with something else; just as, conversely, in truth, the form must be grasped not merely as something dependent on and external to the content, but rather as that which makes the content into a content, into a being-within-self, into something distinct from something else. The true content contains, therefore, form within itself, and the true form is its own content. But we have to know spirit as this true content and as this true form." (E §383z)

8 A less dialectically determined particularity in Spirit's motion might be suggested by Hegel's comment that "Spirit endures contradiction because it knows that it contains no determination that it has not posited itself, and consequently that it cannot in turn get rid of. This power over every content present in it forms the basis of the freedom of spirit. ... actual freedom does not therefore belong to spirit in its immediacy but has to be brought into being by spirit's own activity. It is thus as the creator of its freedom that we have to consider spirit in philosophy. The entire development of the concept of spirit represents only spirit's freeing of itself from all its existential forms which do not accord with its concept; a liberation which is brought about by the transformation of these forms into an actuality perfectly adequate to the concept of spirit." (E §382z) However, the way spirit frees itself from inadequate forms is not by an act of sovereign Sartrean creativity, but by the process described in the Phenomenology and the Logic.

9 Hegel's refusal to melt down all identities is evident from his carefully legitimated divisions within the state, and from his worries about the effects of enduring interest groups upon the legitimacy of democratic governments. His strong emphasis on patriotism and religion are meant to counterbalance the plurality of interests and identities that will continue within the rational state.

10 The writings of Richard Winfield show how one might try to answer this question in the affirmative.

11 The necessity of determinate negation has problems even within Hegel's text, not just because the details seem to go too far. See my Critique of Pure Modernity (Chicago: University of Chicago Press, 1986). 
12 To decide between a hermeneutic Hegelianism and a modest poststructuralism would involve arguments about the role of rational judgment. Roughly speaking, the former would find rational judging as a factor within the process of hermeneutic appropriation and extension, while the latter would take rational schemes as products of the process. In either case, it might seem that lacking either Hegel's assured list of particular moments, or Pippin's relatively self-transparent goal of rationality, a move away from formal modernism would end in a facile relativism. It is true that in a more hermeneutical mode the imperative of increasing self-awareness of the process does not on its own provide usable criteria. But it is never on its own. There are always factical spaces of alternatives and directions and suggestions about ways to go on. Logical space is more Aristotelian than Newtonian. A parallel might be drawn with values such as simplicity in decisions among rival scientific theories. Stated formally, simplicity provides no usable criterion since there are indefinitely many ways in which simplicity might be measured. But some of those ways are already salient, schematizing the formal criterion. That salience is itself changeable, but again there will always be a factical set of axes already in play guiding such change, though, again, those can be changed in similar fashion. In all these changes, on whatever level, there are factical guides and the possibility of changing them, but there is no final court of appeal or formally defined platform which gives the definitive schematization of the relevant values.

13 It is a separate issue to what degree such self-awareness is found only in recent times. In several essays in Postmodern Sophistications (Chicago: University of Chicago Press, 1990). I argue that the awareness is not so restricted, though its institutionalization as central to modes of mutual recognition is new to modernity. 